\title{
Doporučené očekávané výstupy pro environmentální výchovu
}

\author{
Jan Činčera
}

\author{
Envigogika 2011/VI/2- Recenzované články/ Reviewed Papers
}

Publikováno/Published 30. 09. 2011

\section{DOI: http://dx.doi.org/10.14712/18023061.59}

\begin{abstract}
Abstrakt:
Článek prezentuje strukturu a teoretická východiska nově přijatého kurikulárního dokumentu "Doporučené očekávané výstupy pro základní vzdělávání". Text analyzuje jednotlivé části dokumentu, upozorňuje na změny, které dokument přináší pro současnou praxi, i na rozhodnutí, která pracovní skupina autorů při jeho vytváření přijala. Dokument definuje cíle a obsah environmentální výchovy pro oblast základních škol. Podle něj je obecným cílem oboru odpovědné environmentální chování. K dosažení tohoto cíle se mají učitelé zaměřit na pět klíčových a pět propojujících témat. Klíčovými tématy jsou senzitivita, ekologické principy, environmentální problémy a konflikty, výzkumné dovednosti a akční strategie. Propojujícími tématy pak vztah k místu, environmentální postoje a hodnoty, kooperativní dovednosti, přesvědčení o vlastním vlivu a osobní odpovědnost. Článek popisuje teoretická východiska každého tématu, uvádí príklady doporučených očekávaných výstupů a doporučených strategií, které kriticky komentuje.
\end{abstract}

\section{Klíčová slova:}

Kurikulum, Rámcové vzdělávací programy, očekávané výstupy, analýza

\begin{abstract}
:
The article presents structure and theoretical background of newly-launched curriculum document "The Recommended Objectives for Environmental Education for Elementary Schools". The text analyzes all the chapters of the document, highlights changes the document brings to contemporary praxis and discusses decisions made by the authors' group. The document defines goals and content of environmental education for elementary schools. According to it, responsible environmental behaviour is an ultimate aid of environmental education. To achieve this, teachers should focus on five key and five linking topics. The key topics are environmental sensitivity, ecological principles, environmental problems and issues, investigation skills, and action strategies. The linking topics are sense of place, environmental attitudes and values, cooperative skills, internal locus of control, and personal responsibility. The article describes theoretical underpinnings for each of the topics, gives examples of its recommended objectives and strategies, and comments critically all of them.
\end{abstract}

\section{Key words:}

Curriculum, General Educational Programs, objectives, analysis 


\section{Úvod}

V květnu 2011 schválil Výzkumný ústav pedagogický dokumenty Doporučené očekávané výstupy pro základní vzdělávání a Doporučené očekávané výstupy pro gymnázia (Pastorová a kol., 2011). Zakončil se tím projekt, jehož cílem bylo specifikovat očekávané výstupy pro průřezová témata obou rámcových vzdělávacích programů.

V kontextu environmentální výchovy byla taková specifikace velmi potřebná. Environmentální výchova byla $v$ rámcových vzdělávacích programech zpracována značně problematicky. Prưrezové téma Environmentální výchova v RVP pro základní vzdělávání (dále PT EV) trpělo značnou vnitřní nekonzistencí a výběr dílčích témat doporučených k výuce pưsobil dost chaoticky. Podstatnější ale byla naprostá nekonzistence se stavem poznání $v$ mezinárodním oborovém diskursu. Dokument nereflektoval vývoj oboru za posledních čtyřicet let. Doporučoval učitelům soustředit se na předávání dílčích znalostí, a přitom pomíjel klíčovou konativní oblast. Celkovou dikcí i výběrem témat vytvářel iluzi, že cestou k environmentálnímu chování je povědomí o environmentálních problémech, případně nástrojích pro jejich řešení (Činčera, 2008b). Proces př́pravy doporučených očekávaných výstupů pro průřezové téma Environmentální výchovu (dále jen DOV) byl proto provázen vědomím potřeby hluboké paradigmatické změny $v$ domácím chápání oboru, který sdílela celá pracovní skupina.

Článek představuje logiku a teoretická východiska DOV. Je zpracován z pohledu člena pracovní skupiny. Jako takový vysvětluje důvody pro volbu struktury dokumentu i některých použitých formulací. V první části představuje základní východiska DOV a limity jejich zpracování. Ve druhé pak představuje jednotlivé části DOV. Autor předpokládá, že článek otevře širší diskusi o novém pojetí environmentální výchovy a tolik potřebnou kritickou reflexi tohoto oboru.

\section{Základní východiska}

Práce na DOV byla zahájena na podzim 2009. Výzkumný ústav pedagogický (VúP) tehdy sestavil expertní tým, tvořený zástupci vysokých škol (Činčera, Technická univerzita v Liberci, Jančaříková, Univerzita Karlova), středisek ekologické výchovy (Šimonová, Sdružení TEREZA) i škol (Volfová, Gymnázium Elišky Krásnohorské). Svého zástupce měl v týmu také VúP (nejprve Kindlmannová, později Svobodová). VúP přitom souběžně koordinoval práci všech expertních týmů zpracovávajících jednotlivá průřezová témata.

Na samém začátku práce se tým poměrně rychle shodl na potřebě paradigmatické změny v pojetí PT EV. Další práce byla ovlivněna nutností vyvážit požadavky tři odlišných diskursů: oborového, pragmatického a politického.

Oborový diskurs je možné si představit jako způsob, jakým je environmentální výchova interpretována $v$ mezinárodní oborové komunitě, reprezentované jádrovými časopisy, jako je The Journal of Environmental Education, Environmental Education Research, Canadian Journal of Environmental Education a další. Pracovní skupina se zde potýkala s několika problémy. Prvním byla nepropojenost domácího odborného prostředí se zahraničním. Do vzniku časopisu Envigogika u nás témata řešená $v$ mezinárodních časopisech $v$ podstatě nebyla diskutována a i od jejího vzniku je taková diskuse ve větším měř́tku dosud velmi vzácná. Mezi domácím a mezinárodním diskursem tak existuje čtyřicet let široká propast, kterou je prakticky nemožné překonat jedním dokumentem.

Druhým problémem byla různorodost přístupů existujících $v$ rámci mezinárodního diskursu. Zjednodušeně Ize říct, že přestože $v$ mezinárodní literatuře existuje $v$ pojetí oboru taková míra shody, která umožňuje mluvit o společném diskursu, existuje zde i několik "konkurenčních" proudů. Zřetelný je například rozdíl mezi „americkým" 
přístupem, který je do značné míry reprezentován časopisem The Journal of Environmental Education a doporučujícími standardy Severoamerické asociace pro environmentální výchovu (NAAEE), a tradicemi rozvíjenými v Kanadě, Austrálii, Británii či severní Evropě. Nevyřešeným tématem je také vztah k novější výchově k udržitelnému rozvoji, která je některými autory chápána jako nová generace environmentální výchovy, jeden z jejich přístupů, nadřazená oblast či svébytný výchovně vzdělávací proud (Činčera, 2008a; Wals, 2009). Pracovní skupina tedy musela volit, ke které tradici se ve svém návrhu přikloní, respektive jakou kompilaci $z$ nich provede.

Pracovní skupina se $\mathrm{v}$ návrhu DOV $\mathrm{v}$ zásadě přiklonila $\mathrm{k}$ americkému pojetí environmentální výchovy, se zohledněním několika dalších přístupů. Jakékoliv rozhodnutí v této otázce nutně přináší svoje výhody i nevýhody. Lze předpokládat, že environmentální výchova $v$ té podobě, jak ji chápou např́klad představitelé severského proudu (Jensen \& Schnack, 2006; Breiting, 2009; Östman \& Öhman, 2007; Schnack, 2009), kritického či transformačního přístupu (Kahn, 2007; Sterling, 2001; Bowers, 2002; Räthzel \& Uzzell, 2009; Gruenewald, 2008) by pro stávající domácí kontext byla většinově obtížně přijatelná. V americké tradici je environmentální výchova chápána jako prưřezová, přírodovědně-společenská disciplína, což není od domácího, převážně naturalistického pojetí (Sauvé,2005) vzdáleno tolik, jako některé výše zmíněné přístupy, upřednostňující její sociální dimenzi nad prírodovědnou (srv. Jensen \& Schnack, 2006). Americká tradice také klade větší důraz na individuální chování a odpovědnost, což mưže být $v$ českém historickém kontextu snáze akceptovatelné, než upřednostňování kolektivní akce či volání po hlubší přeměně společnosti. Pracovní skupina $v$ největší míře vycházela zejména ze standardů NAAEE, což ovšem přineslo další specifické problémy, související především s otázkou kompatibility mezi domácím a mezinárodním výchovně-vzdělávacím kontextem.

Pragmatickým diskursem je zde míněn způsob, jakým bude dokument komunikován směrem k jeho uživatelům, tj. učitelům na základních školách a gymnáziích. Je zřejmé, že pokud má být dokument používán v praxi, musí být pro svoji cílovou skupinu srozumitelný. Pracovní skupina vycházela z předpokladu, že interpretace environmentální výchovy na školách bude odpovídat tomu, co bude $v$ novém dokumentu zdůrazněno. Za nezbytné proto požadovala začlenění vysvětlujících pasáží a příkladů. Dalším problémem byla otázka nově použitých termínů, které často neměly zavedené české ekvivalenty. Pracovní skupina pak řešila dilema volby mezi přesností překladu a j srozumitelností termínů pro cílovou skupinu.

Politickým diskursem se zde myslí hranice možností, které byly předem definovány VúP. Je zřejmé, že každý koncepční dokument obsahuje politickou dimenzi. VúP bylo v době přípravy projektu organizací řízenou Ministerstvem školství, mládeže a tělovýchovy, které určuje svoji představu o cílech vzdělávání v závislosti na politickém programu stran zastoupených $v$ jeho vedoucích strukturách. Politicky citlivou otázkou se ukázalo zejména nahrazení původního PT EV novým dokumentem navržené pracovní skupinou. Výsledkem proto byl (poněkud matoucí) kompromis, který „propojuje" novou logiku DOV se "starou" strukturou stávajícího PT.

Př́kladem takového kompromisu je i použitá terminologie, podle které jsou DOV rozděleny na klíčová a propojující „témata". Pojem „téma” je zde použit kvưli kompatibilitě s tematickým členěním PT. DOV ale ve své podstatě nejsou rozděleny do jednotlivých témat, spíše do vzájemně navazujících oblastí. Pracovní skupina při strukturování DOV vycházela především z terminologie používané v modelu odpovědného environmentálního chování (REB), který definuje jednotlivé proměnné klíčové pro rozvíjení proenvironmentálního chování (Hungerford \& Volk, 1990), v menší míře pak z okruhů definovaných ve standardech NAAEE (2004), označovaných zde jako „paprsky”. DOV předpokládá, že učitelé by měli postupně rozvíjet všechny klíčové oblasti, smysl tedy není ve výběru několika "témat", ale v celku. Propojující "témata" jsou pak spíše určitými "akcenty" pomáhajícími zaměřit naplňování klíčových oblastí v souladu s intencí autorů dokumentu. 
Do určité míry politickou otázkou byl i proces zpracovávání DOV. Představy nezávisle pracujících skupin řešících jednotlivá průřezová témata byly v závěrečné práci slad'ovány garanty za VúP, což vedlo k dílčím konfliktům. VúP také př́liš nefacilitoval diskusi mezi jednotlivými týmy. V důsledku nejsou průřezová témata provázána tak, jak by bylo vhodné.

V důsledku je třeba chápat DOV jako kompromisní dokument, jehož odborná čistota je na mnoha místech poznamenána vyvažováním a vyjednáváním mezi jednotlivými diskursy.

\section{Analýza DOV}

Úvod

V úvodní části DOV definují cíle a obsah environmentální výchovy. Environmentální výchova je zde definována jako výchova, která „vybavuje žáky specifickými kompetencemi, které směřují k odpovědnému environmentálnímu chování, tj. takovému chování, kdy lidé berou při svém rozhodování v potaz dopady možných řešení na životní prostředí a zapojují se do aktivit určených ke zvýšení kvality životního prostředí a kvality vlastního života." (Pastorová a kol., 2011, s. 54). Tato definice představuje základní východisko celého dokumentu. Odpovědné environmentální chování jako cíl environmentální výchovy je uveden ve všech klíčových dokumentech vymezujících obor (viz Deklarace z Tbilisi, 1977) i v textech korespondujících s americkou tradicí (Stapp, 1969 in 2005; Hungerford et al., 1980; Hungerford \& Volk, 1990; Disinger, 2005). DOV dále navazuje na koncept „kvality života” používaného pro legitimizaci obecného cíle environmentální výchovy (The Belgrade Charter, 1975; Hungerford et al., 1980). Použití pojmu "kompetence" současně znamená úkrok směrem k severskému proudu, který namísto "chování" chápe jako hlavní cíl environmentální výchovy rozvíjení "akčních kompetencí" (Jensen \& Schnack, 2006). DOV se tedy ve vymezení cílů environmentální výchovy snaží o nalezení určitého kompromisu mezi americkou a evropskou tradicí.

DOV dále konstatuje, že "Odpovědné chování nelze ovlivnit pouhým předáváním znalostí o životním prostředí. Je ovlivňováno komplexem vzájemně provázaných specifických znalostí, dovedností a postojü, které se u žáků v rüzném období rozvíjejí a navazují na sebe." (s. 54) Tuto část je třeba chápat jako prostředek pragmatického diskursu. DOV se $v$ této části a) vyhrazuje proti stávajícímu znalostnímu pojetí PT, b) směruje čtenáře $k$ interpretaci dokumentu jako celku, nikoliv výčtu dílčích témat, ze kterých je možné vybírat si podle potřeby.

DOV dále vysvětluje strukturu klíčových a propojujících témat a graficky je znázorňuje $v$ modelu, kterému se v praxi začalo neformálně říkat "cibule". DOV se skládá z pěti klíčových témat (senzitivita, zákonitosti, výzkumné dovednosti, problémy a konflikty, akční strategie), která jsou vzájemně provázána pomocí pěti propojujících témat (vztah k místu, přesvědčení o vlastním vlivu, osobní odpovědnost, kooperativní dovednosti, environmentální postoje a hodnoty). DOV konstatuje, že uvedená témata "byla definována na základě osvědčených zahraničních modelư environmentální výchovy" (s. 54). Teoretické zázemí pro každé téma bude analyzováno $v$ dalším textu. Zde je na místě uvést, že zejména ve volbě propojujících témat se autorskému týmu nabízely i jiné možnosti. Tým například diskutoval o zařazení vztahu k místu mezi klíčová či propojující témata. Bylo by možné rozlišovat mezi obecnými a specifickými proenvironmentálními postoji či důsledněji rozlišovat postoje, přesvědčení a hodnoty. Zařazení kooperativních dovedností do propojujících témat odráží spíše domácí tradici environmentální výchovy, naopak rozlišování mezi "přesvědčením o vlastním vlivu" a "osobní odpovědností" je poplatné pracím vycházejícím z modelu REB (Hungerford \& Volk, 1990; Marcinkowski, 1997; Hwang, Kim \& Jeng, 2000; Marcinkowski, 2005). Pracovní skupina se tedy v rámci možných variant přiklonila $\mathrm{k}$ jedné, která má na jedné straně oporu v literatuře, na druhé 
je ve své podobě jedinečná a specificky „česká". To samozřejmě opět přináší kromě výhod i nezanedbatelná rizika.

DOV dále navrhují určitou časovou posloupnost v naplňování jednotlivých klíčových oblastí. Návrh zcela vychází z logiky modelu REB a navazujících doporučení (Hungerford \& Volk, 1990; Disinger, 1997; Hungerford \& Volk, 2005; Volk, 2005; Ramsey et al., 2005). Výuka by se u mladších dětí měla soustředit především na rozvíjení environmentální senzitivity a porozumění základním ekologickým principům. Teprve po vybudování této základní báze by se měl dưraz přesunout na rozvíjení výzkumných dovedností, dále aplikovaných pro analýzu environmentálních problémů a konfliktů. Rozvíjení znalostí a dovedností asociovaných s akčními strategiemi by pak mělo logicky navazovat na analyzované problémy a konflikty (s. 55). DOV zde říká učitelům: nejprve u dětí rozvíjejte základní motivaci $\mathrm{k}$ tomu zabývat se životním prostředím (senzitivita) a ved'te je k porozumění základním principům fungování přírody (zákonitosti). Rozvíjejte jejich schopnosti samostatně si klást otázky a hledat na ně odpovědi (výzkumné dovednosti). Teprve potom dejte dětem př́ležitost zkoumat zvolené problémy a naučte je, jak do nich mohou samy vstupovat.

Není sporu o tom, že uvedená sekvence není jedinou možností, jak časově uspořádat školní kurikulum. Jak dokument konstatuje, uvedenou sekvenci je třeba chápat jako orientační a vždy je třeba vycházet z individuálních potřeb žáka a místního kontextu (s. 55). Její zohlednění ale může být dobrou prevencí před některými modelově špatnými strategiemi environmentální výchovy na školách. Těmi jsou především přiliš brzké konfrontování dětí s environmentálními problémy, a) pro jejichž pochopení nemají vypracovaný pojmový aparát, b) které ještě nedokážou samostatně analyzovat, c) se kterými nedokážou nic dělat (Hicks \& Bord, 2001).

V poslední části úvodu DOV propojuje klíčová témata s tematickými okruhy v RVP. Uvedená tabulka (s. 55) je součástí politického diskursu. DOV a stávající PT jsou zpracovány podle zcela odlišné logiky a jejich propojování je umělé a matoucí. Jedinou výhodou mưže být snazší přechod škol ze stávajícího nastavení PT ve svých ŠVP na DOV.

\section{Environmentální senzitivita}

Prvním z klíčových témat DOV je environmentální senzitivita. V DOV je definována jako "citlivost, vztah a empatie vưči přírodě a životnímu prostředí, včetně citlivého vztahu ke zvíratưm a rostlinám." (s. 56) Tato definice je v souladu s Petersonovou (2005), která definuje environmentální senzitivitu jako "sadu afektivních atributů, jejichž důsledkem je individuální pohled na životní prostředí z empatické perspektivy" (Peterson, 2005, s. 296); s environmentální senzitivitou je dále asociován pocit blízkosti a sounáležitosti s prírodním prostředím (Marcinkowski, 1997).

Zařazením senzitivity mezi klíčová témata DOV provedla pracovní skupina poměrně odvážné rozhodnutí, vycházející zejména ze zohlednění domácí tradice environmentální výchovy. Postavení environmentální senzitivity $v$ oborovém diskursu je totiž určitým způsobem problematické. Environmentální senzitivita je $v$ modelu REB charakterizována jako jedna z klíčových proměnných (Hungerford \& Volk, 1990). Na druhé straně je třeba uvést, že do dalších modelů proenvironmentálního chování není zahrnována, přestože může souviset $s$ problematikou environmentálních hodnot (Stern a kol., 1999; Kollmuss \& Agyeman, 2002; Heimlich, 2008). Environmentální senzitivita dále nebývá zařazována do doporučení pro školní kurikula a není ani součástí doporučení NAAEE (2004). Podle Hungerforda, Peytona a Wilka (1980) nemůže být environmentální senzitivita operacionalizována do měřitelné podoby, je příliš individuální a je spíše výsledným efektem, než bezprostředním výstupem programů.

Výzkum environmentální senzitivity $v$ zásadě vychází ze dvou linií. První jsou kvalitativní výzkumy významných životních zkušeností (significant life experience, SLE) respondentů, ve svém profesním životě aktivně působících v oblasti životního prostředí (Chawla, 1998; Chawla, 1999; Palmer a kol., 1998; Peterson, 2005). Druhou pak kvantitativní či smíšené výzkumy, operacionalizující environmentální senzitivitu pomocí 
kategorizovaných zkušeností s přírodou či podle jiného klíče (Sivek, 2002; Marcinkowski, 1997).

DOV charakterizují význam environmentální senzitivity a doporučují strategie k jejímu rozvíjení. I tyto pasáže je třeba podrobit hlubší analýze. Podle DOV je environmentální senzitivita „....základním předpokladem $k$ projevení zájmu učit se o životním prostředí, mít o něj starost a podnikat kroky k jeho ochraně. Rozvíjením environmentální senzitivity ovlivňujeme ranou motivaci dětí diskutovat a zkoumat otázky životního prostředí, jde proto o vstupní a klíčovou oblast environmentální výchovy. Čím více žáci pobývají $v$ prírodě, tím více podporují jako dospělí péči o životní prostředí." (s. 56).

Zatímco první dvě věty je možné chápat jako rozvedení popisu proměnné z modelu REB, poslední věta se odkazuje na výzkumy SLE. Tuto pasáž je třeba chápat jako projev pragmatického diskursu. Výzkumy SLE z rưzných zemí skutečně ukazují, že respondenti aktivně působící v oblasti životního prostředí nejčastěji uvádějí jako klíčový faktor jejich životní dráhy právě dlouhodobé, opakované a pozitivní zkušenosti s pobytem v prírodě (Sward \& Marcinkowski, 2005; Peterson, 2005; Vadala et al., 2007; Chawla, 1999). Na druhé straně by čistá kauzalita mezi délkou pobytu $v$ prírodě a mírou proenvironmentálního chování byla proti samotné logice DOV. Jak uvádí Krajhanzl (2009; 2010), můžeme najít řadu př́kladů, které tuto kauzalitu rozporují: problematické chování obyvatel menších obcí, prírodních národů atd. Dlouhodobost a opakovanost pobytu v př́rodě je zřejmě třeba chápat jako jeden $z$ faktorů, který sice může vést k proenvironmentálnímu chování, ale zřejmě pouze ve spojení s dalšími faktory. Těmi mohou být další proměnné definované $v$ REB či jiných modelech proenvironmentálního chování.

Důležitou roli ale zřejmě hraje i to, jakým způsobem děti svůj prožitek pobytu v prírodě interpretují. Vadalová a kol. (2007) navrhují rozlišovat mezi dvěma mody dětského pobytu v prrírodě: hrou v přírodě a hrou s přírodou. Pro rozvíjení environmentální senzitivity je podle ní důležitější právě hra s přírodou, tj. přímá interakce dítěte s okolním prostředím. Podobné závěry naznačují například i rozdílné výsledky evaluačních výzkumů programů tři různých outdoorových organizací (Outward Bound, National Ooutdoor Leadership School a Student Conservation Association). Programy organizace Outward Bound využívají přírodu jako prostředí pro osobnostní rozvoj účastníkư. Příroda je zde zdrojem situací, které pro účastníky znamenají určitou výzvu, pro jejíž zvládnutí musí spolupracovat s ostatními a překonat své osobní limity. Programy Outward Bound prokázaly svůj vliv na osobnostní charakteristiky účastníků, ale nijak výrazně neovlivnily vztah účastníků k přírodě. Na druhé straně outdoorové programy organizace Student Conservation Association se cíleně zaměřuji na rozvíjení vztahu účastníků k okolnímu prostředí. Evaluační výzkum prokázal, že pobytové akce tohoto sdružení skutečně změnily postoje účastníků k př́rodě (Kellert, 1998).

Pro rozvíjení environmentální senzitivity DOV doporučuje zabezpečit žákům častý kontakt s prírodou a prostor pro samostatné interakce s přírodou a pro její poznávání. Kontakt $s$ prírodou by měl být pro žáky příjemný a bez stresujících zážitků. To koresponduje např́klad s výzkumem v oblasti SLE Vadalové a kol. (2007), která na srovnání dvou skupin respondentů ukazuje, jak stresující zážitky zablokovaly vztah respondentů $\mathrm{k}$ přírodě. DOV dále konzistentně $\mathrm{s}$ výzkumy SLE doporučuje využívat pobytové akce v prírodě, školní zahradu či vzor vyučujícího, naopak varuje před strašením žáků katastrofickými předpověd'mi (s. 56), na druhém stupni pak uvádí další méně významné strategie (např. čtení knih, př́běhy (s. 57)).

Vzhledem k tomu, že při vymezení očekávaných výstupů pro toto téma se pracovní skupina nemohla opřít o doporučené standardy NAAEE, bylo jeho zpracování velice náročné. Výsledek tak vyžaduje hlubší analýzu; ta se může týkat zejména dvou diskutabilních bodů. 
Prvním byla otázka formulace výstupů $v$ této afektivní oblasti. Má být očekávaným výstupem to, že děti "budou mít rády prírodu" a "budou se v ní cítit dobře", nebo je dostačující, pokud "libovolnou formou vyjádří, čím je pro ně príroda" a "vyjádří své pocity při fyzickém kontaktu s př́rodou" (s. 56). Pracovní skupina, ale i vúP, se důsledně snažili nepředepisovat žákủm zaujímání konkrétních postojů k životnímu prostředí a na místo toho používali dovednostní formulace typu "zdůvodní", "vyjádř́i", "popíše" atd. Zvolené řešení má své výhody i rizika. Očekávané výstupy v DOV jsou ověřitelné, ne-manipulativní a neideologické. Připouštějí, aby děti zaujaly vlastní postoje, názory a přesvědčení související s prrírodou a životním prostředí a nenutí je $\mathrm{k}$ zaujetí postojů předepsaných kurikulem. To koresponduje s doporučeními řady autorů. Podle Hungeforda (2005b) je naprosto neakceptovatelné, aby učitel vyučoval žáky, jaké mají mít hodnoty. Na druhé straně zcela doporučuje to, aby učitelé rozvíjeli u žáků dovednosti pro identifikaci svých hodnot i hodnot jiných lidí (s. 55).

Ovlivňování postojů a hodnot je ale součástí definic environmentální výchovy z Bělehradské charty i Tbiliské deklarace a představuje tak podstatnou část vymezení oboru (The Tbilisi Declaration, 1977; The Belgrade Charter, 1975). Nabízí se proto otázka, zda „pozitivní postoje" $\mathrm{k}$ př́rodě nejsou přirozenou "žádoucí oblastí environmentální výchovy, a zda řešení navržené $v$ DOV neotevírá cestu k relativizaci environmentálních hodnot.

Řešením tohoto dilematu může být důsledné rozlišování mezi cíli (goals) vyjadřujícími intenci společnosti či pedagoga a výstupy (objectives) vymezujícími výkon žáka (Sellers, 2007; Hungerford, 2005). V takovém př́ípadě je formování postojů možné chápat jako legitimní cíl, ale nelegitimní výstup. Takové rozlišování ale není v domácí pedagogické literatuře obvyklé a například Pedagogický slovník (Průcha, Walterová \& Mareš, 2009) pojem "výstupy" vůbec neobsahuje.

Druhou spornou otázkou je obsahové vymezení environmentální senzitivity v DOV. Toto klíčové téma $v$ DOV obsahuje několik různých podoblastí:

- Osobní vztah k prírodě

- Vnímavost vůči př́rodě

- Ohleduplné chování vůči př́rodě

- Interpretace místa či regionu

- Estetická reflexe prírody

- Etická reflexe př́rody.

Tento záběr představuje značné rozšíření definice oproti vymezení environmentální senzitivity podle Petersonové (2005), které by korespondovalo jen s prvními třemi body. Pracovní skupina zde narážela na tradici i meze domácího pojetí. V Ceské republice není dosud rozpracována teorie environmentální interpretace ${ }^{1}$ (Knapp, 2005). Její obsah se proto zčásti rozpustil do Senzitivity, dále je zahrnut v propojujícím tématu Vztah k místu. $\checkmark$ České republice je naopak silná tradice $v$ zařazování programů zaměřených na environmentální etiku, která proto byla do klíčového tématu začleněna, přestože její souvislost s environmentální senzitivitou může být problematická.

\footnotetext{
${ }^{1}$ Environmentální interpretace se zaměřuje na komunikaci významů kulturního a př́rodního dědictví. Vztahuje se vždy ke konkrétnímu místu a probíhá v neformálním prostředí (Back \& Cabel, 2002).
} 
Celkově Ize říct, že pracovní skupina se pokusila vymezit toto klíčové téma tak, aby podpořila zařazování programů, ve kterých děti reflektují svůj vztah k př́rodě na rovině estetické, racionální i perceptivní. Rizikem je, že značný záběr tématu umožní legitimizovat programy S vágními, proklamativními a nerealistickými ambicemi formovat „vztah k prrírodě". Prevencí může být pouze zavedení vyhodnocování účinku programu na účastníky, které by takové programy identifikovalo a vyřadilo.

\section{Zákonitosti}

Druhé klíčové téma je v DOV definováno jako „znalosti základních principů fungování životního prostředí, tedy to, "jak to obvykle v přírodě chodí"." (s. 57). Zpracování tématu bylo ve srovnání se Senzitivitou nepoměrně méně náročné. Zákonitosti korespondují s domácí naturalistickou tradicí zdůrazňující roli "ekologie" v environmentální výchově. Celá oblast je současně velmi dobře zpracována $v$ doporučujících standardech NAAEE (2004a).

Porovnání se stávajícím PT EV nicméně ukazuje významný posun. Zjednodušeně Ize říct, že PT akcentuje „prvky”, zatímco DOV "procesy”. Ty jsou v DOV obdobně jako v NAAEE definovány jako a) toky energie a koloběhy látek, b) potravní řetězce, c) vztahy mezi organizmy a prostředím, d) sociální struktura populací a společenstev a antropogenní vliv na životní prostředí (s. 57). DOV doporučuje využívat terénní výuku, vlastní průzkum a propojování s každodenním životem dětí (s. 57). To může představovat dílčí posun oproti časté praxi výuky ekologických zákonitostí jako abstraktních principů v učebně.

V modelu REB se předpokládá, že ekologické znalosti nekorelují s odhodláním jedince chovat se odpovědně k životnímu prostředí, ale že mohou mít vliv na kvalitu přijatého rozhodnutí (Hungerford \& Volk, 1990). Zařazení Zákonitostí mezi klíčová témata odráží vliv amerického modelu i domácí tradice. Současně je zjevné, že ve srovnání se stávajícím PT EV je v DOV význam ekologických znalostí výrazně snížen.

\section{Problémy a konflikty}

Třetí klíčové téma zavádí do domácího diskursu pojem environmentálních konfliktů (environmental issue) a jejich rozlišení od environmentálních problémů (environmental problems): "Jako environmentální problémy se označují objektivně existující problémy životního prostředí, které mohou, ale nemusí být způsobeny lidskou činností. Problémy vznikají tehdy, je-li $v$ ohrožení něco, co je pro někoho hodnotou. Environmentální problémy jsou kriticky zkoumány pomocí metod prírodních a společenských věd a žáci se seznamují s jejich podstatou a vědeckou reflexí. Environmentální konflikty predstavují společenskou diskusi o řešení problémů. Vznikají tehdy, pokud existují rưzné názory na řešení daného problému." (s. 59). Tato definice odpovídá vymezení Hungerforda a Volkové (1990, s. 17): "Environmentální problém vzniká, pokud se něco dostane do nebezpečí, např́klad zvírata se stanou ohroženými. Environmentální konflikt vzniká tehdy, mají-li lidé různá přesvědčení a hodnoty související s tím, co by se s problémem mělo dělat, např́klad se liší v názoru na to, co by se mělo dělat s ohroženými druhy."

V mezinárodním oborovém diskursu Ize za posledních třicet let vidět zřetelný trend přesunu pozornosti od environmentálních problémů $\mathrm{k}$ environmentálním konfliktům. Environmentální výchova, která se soustředí na vzdělávání o problémech, bývá označována jako výchova založená na uvědomění (awareness-oriented). Oproti tomu za žádoucí je považována výchova, která vychází z analýzy a řešení konkrétních environmentálních konfliktů (action-oriented) (Hungerford \& Volk, 1990; Hungerford \& Volk, 2005b; Ramsey, Hungerfod \& Volk, 2005). V tomto ohledu se shodují americká i moderní evropské tradice. Rozdíly jsou pak spíše v důrazu. Americká tradice vycházející z Hungerforda, Marcinkowského a dalších autorů upřednostňuje spíše silnější vstupní prípravu žáků na analýzu konfliktů a předchozí rozvíjení vstupních proměnných (Marcinkowski, 2004; Bardwell et al., 2004). Jensen, Schnack, Breiting a další představitelé severského proudu kladou do centra pozornosti rozvíjení kompetencí souvisejících s řešením konfliktů (Jensen \& Schnack, 2006; Schnack, 2009). Lundegård 
a Wickman (2007) upozorňují, že většina environmentálních témat má charakter konfliktu. Sterling (2001) pak tento trend ještě více posiluje a podporuje chápání školy jako místo kritické analýzy a proměny společnosti.

Pracovní skupina zde řešila, jak v domácí, na problémy a uvědomění orientované tradici, nastartovat adekvátní posun. Řešení představuje určitou formu kompromisu. Většina navržených výstupů je formulována tak, že je Ize použít pro analýzu jak problému, tak konfliktu. To mưže vést $\mathrm{k}$ tomu, že se některé školy analýze environmentálních konfliktů vyhnou. Vzhledem $\mathrm{k}$ nepovinnému charakteru celého dokumentu ale nelze tomuto riziku zabránit.

\section{Výzkumné dovednosti a znalosti}

Čtvrté klíčové téma má rozvíjet "schopnosti žáků samostatně zkoumat environmentální problémy a konflikty a vyhodnocovat jejich možná řešení. Prostřednictvím výzkumných znalostí a dovedností se žáci učí formulovat jednoduché výzkumné otázky a navrhovat základní postupy výzkumu (sbírat potřebná data, uspořádat je, vyhodnotit a interpretovat)." (s. 60). Zařazení výzkumných dovedností mezi klíčová témata i jejich zpracování vychází z doporučujících standardů NAAEE (2004a) a je tedy dalším styčným bodem DOV s americkou tradicí.

Pracovní skupina $v$ rozhodnutí zařadit tuto oblast mezi klíčová témata vycházela z názoru, že rozvíjení výzkumných dovedností patři v České republice mezi dlouhodobě podceňovaná témata a je proto žádoucí je $v$ kontextu environmentální výchovy podpořit. To koresponduje $s$ výzkumy PISA z posledních let, které ukazují, že čeští žáci v dovednostech potřebných pro samostatnou analýzu životního prostředí a environmentálních konfliktů (jako je schopnost využívat přírodovědné poznatky v praxi či analýza psaného textu) v mezinárodním měřítku zaostávají (Palečková, 2006; Palečková et al., 2010). I dílčí výzkumy, jako byl například evaluační výzkum programu GLOBE, ukazují, že výzkumné dovednosti v oblasti environmentální výchovy nejsou na školách adekvátně rozvíjeny. Žáci se zpravidla účastní učitelem řízených aktivit, jako je práce s pracovními listy či sběr dat $v$ terénu. Výrazně méně se ale učí samostatně si plánovat výzkum nebo interpretovat naměřená data (Činčera \& Mašková, 2011).

Na př́kladě výzkumných dovedností je možné znovu upozornit na systémový charakter celého dokumentu. Aby získali žáci motivaci zapojit se do řešení určitého konfliktu, potřebují jej samostatně zkoumat. Aby jej mohli zkoumat, potřebují k tomu výzkumné dovednosti.

Současně je důležité uvědomit si problémy, související s odlišnostmi mezi domácím a zahraničnímvýchovně-vzdělávacím kontextem. Pokud rozvoj výzkumných dovedností představuje v českém školství dlouhodobě nezvládnutou oblast, hrozí, že nebude fungovat transfer zahraničních metod ze zemí s odlišnou tradicí. Je nerealistické předpokládat, že to bude environmentální výchova, kde se žáci naučí formulovat výzkumné otázky, kriticky analyzovat texty, plánovat výzkum či interpretovat data. Koncepci DOV nelze naplnit "infúzním" přístupem, je nemyslitelná bez důkladné integrace a propojení s celým ŠVP. To klade velké nároky na školní koordinátory environmentální výuky a jejich schopnost plánovat, spolupracovat a komunikovat s ostatními členy pedagogického sboru.

\section{Akční strategie}

Poslední klíčové téma zahrnuje „znalosti a dovednosti potřebné k tomu, aby žáci mohli přijmout takové jednání, které $v$ dané situaci povede $k$ environmentálně nejpříznivějším důsledkům." (s. 61) DOV se zde znovu vrací k odpovědnému environmentálnímu chování jako hlavnímu cíli environmentální výchovy. $V$ plném souladu s americkou tradicí je odpovědné environmentální chování rozděleno do pěti oblastí: ekomanagement (jednání, ve kterém jsou žáci v přímém kontaktu s přírodou či přírodními zdroji), spotřebitelství (jednání, ve kterém žáci ovlivňují trh využitím své kupní síly, např. nákup výrobků s ekoznačkou), přesvědčování (jednání, kdy žáci ovlivňují jiné lidi k odpovědnému environmentálnímu chování), politické akce (jednání, ve kterém žáci např. 
komunikují se zastupiteli, dospělí pak mohou rozhodovat o výběru kandidátů při volbách) a právní akce (jednání, kdy žáci využívají existující právní nástroje, např. píší petice či dávají podněty $\mathrm{k}$ trestnímu stíhání, dospělí pak se mohou účastnit rủzných rozhodovacích procesů). (s. 61-2)

Vymezení klíčové oblasti je odvozeno jak z doporučujících standardů NAAEE (2004), tak z literatury o REB. V té se pracuje s pojmy "akční znalosti (action knowledge)" a "akční dovednosti (action skills)", v praxi jsou ale tyto pojmy málokdy od sebe oddělovány. Obě proměnné jsou považovány za významný prediktor proenvironmentálního chování. Zařazení akčních strategií dále koresponduje s Ajzenovou teorií plánovaného chování (Ajzen, 1991), podle které je jednou ze tří hlavních proměnných korelujících s odhodláním $\mathrm{k}$ jednání přesvědčení o zvládnutí zvažované činnosti. Zjednodušeně Ize říct, že lidé se pravděpodobně neodhodlají k odpovědnému chování, pokud nebudou přesvědčeni, že ho zvládnou. Cestou k takovému přesvědčení je osvojení potřebných znalostí a dovedností a jejich aplikace $v$ konkrétní situaci.

I $\vee$ tomto prípadě pracovní skupina řešila problémy související $s$ domácí tradicí. $V$ té jsou velmi výrazně akcentovány programy zaměřené do oblasti ekomanagementu a v menší miře spotřebitelství, zatímco ostatní oblasti chování se objevují jen marginálně (Činčera et al., 2009). Paradoxně tak $\mathrm{k}$ nejrozšířenějším programům korespondujícím $s$ touto oblastí patři programy na trídění odpadů, přestože pokrývají jen jeden, poměrně snadno realizovatelný aspekt proenvironmentálního chování.

Pracovní skupina zde dlouho diskutovala o adekvátní české terminologii. Pojem „akční strategie" pravděpodobně není z hlediska pragmatického diskursu optimální, ale pracovní skupině se nepodařilo najít jiný stručný a výstižný ekvivalent. Dalším problémem byl pojem "ekomanagement" a vlastně i celé vymezení pěti oblastí proenvironmentálního chování, na kterém je patrná odlišná tradice místa původu. V českém prostředí se například používá pojem "domácí ekologie", který ovšem odkazuje na chování v domácnosti na rozdíl od širšího "ekomanagementu". Rozdělení oblastí proenvironmentálního chování na "domácí, profesní, občanské a spotřebitelské", se kterým je také možné se u nás setkat, zase vyvolává jiné komplikace. $V$ americké tradici je environmentálně odpovědné chování chápáno jako projev environmentálně odpovědného občanského chování (Hungerford \& Volk, 1990) a není zřejmé, proč by "občanské" chování mělo být odděleno od domácího či spotřebitelského, ani co má vlastně zahrnovat. Pracovní skupina každopádně považovala za důležité zdůraznit, že odpovědné chování zahrnuje i jiné oblasti, než tradiční třídění odpadů a šetření zdroji, přestože ty jsou doporučovány jako prioritní pro první stupeň (s. 62).

\section{Propojující témata}

$\mathrm{K}$ pěti klíčovým tématům připojuje DOV pět propojujících. $U$ propojujících témat nejsou navrženy očekávané výstupy. DOV zde předpokládá, že propojující témata budou hrát roli určitých akcentů, které pomohou učitelưm pochopit logiku klíčových témat a správně je ve svém kontextu implementovat.

Prvním propojujícím tématem je Vztah k místu. Pracovní skupina nejprve předpokládala, že se vztah k místu objeví mezi klíčovými tématy, teprve později byl přesunut mezi témata propojujíć. Téma reflektuje jeden $z$ vlivných proudù současné environmentální výchovy, označovaný jako "v místě zakotvená / lokální výchova" (placebased education). Definice tématu je převzata z Ardoinové (2009). Dưraz na využití místního kontextu je ale $v$ současné environmentální výchově široce přjímán. DOV uvádí několik př́kladů využití místního kontextu $v$ environmentální výchově, jako je práce s místní komunitou, propojení školních jídelen s místními zemědělci atd. (s. 63). Uvedené př́klady pochází z publikací Sobela (2005) a souvisejícího proudu označovaného jako výchova k ekogramotnosti (Capra 2007). 
Přesvědčení o vlastním vlivu je pragmatickým diskursem formovaný překlad proměnné, označované jako internal locus of control. Podle modelu REB je právě přesvědčení o tom, že jedinec mưže svým chováním ovlivňovat stav okolního prostředí, jednou z velmi silných proměnných vedoucích $k$ odhodlání k proenvironmentálnímu chování (Hungerford \& Volk, 1990). Určitou analogii můžeme vidět s Ajzenovým přesvědčením o zvládnutelnosti určitého chování (1991), přestože obě proměnné zjevně nejsou totožné. V kontextu DOV jsou jádrem tématu dvě pasáže: "žák odmítne názor vyjadřující (...) to, že jedinec nic nezmůže a o problémech rozhoduje někdo jiný" a doporučení: "umožňovat jim zapojovat se do takových úkolů, ve kterých mají šanci zažít úspěch spojený s konkrétním pozitivním dopadem na životní prostředí" (s. 64).

Třetím propojujícím tématem je Osobní odpovědnost. Odpovědnost se objevuje jako proměnná související s proenvironmentálním chováním v REB modelu (Hungerford \& Volk, 1990). Do určité míry může být diskutabilní, zda tuto proměnnou zahrnovat do DOV pro environmentální výchovu. Pracovní skupině se nicméně zdálo důležité zdůraznit, že "Žáci by proto měli dostat přiležitost $k$ tomu prijímat ve škole odpovědnost za úspěch společných projektů i dílčích aktivit." (s. 64). Jak upozorňuje de Young (2000) či Darnerová (2009) pro vznik intrinsické2 motivace k proenvironmentálnímu chování je nezbytný prostor pro samostatnou iniciativu a s ní související odpovědnost za výsledek. Na evaluačním výzkumu programu Zelená škola na Slovensku (Činčera, 2010) můžeme ilustrovat, že pokud iniciativu za ekologizaci školy vezme na sebe učitel, děti nerozvíjí své environmentální kompetence a program nevede ke změnám v jejich environmentálním chování.

Zařazení kooperativních dovedností mezi propojující témata může být opět do určité míry problematické. Kooperativní dovednosti jsou součástí jiných kapitol RVP a samy o sobě s environmentální výchovou nesouvisí. V pracovní skupině nicméně převážil názor, že spojení kooperativních dovedností s environmentální výchovou odpovídá domácí tradici a že naplnění záměru DOV není myslitelné bez širokého použití kooperativních metod výuky.

Zařazení posledního propojujícího tématu, environmentálních postojů a hodnot, mezi propojující témata může být z hlediska domácí tradice spíše překvapivé než problematické. V domácím diskursu bývá role postojů a hodnot často zdưrazňována. Faktický vliv proenvironmentálních postojů a hodnot na odhodlání k chování je ale problematický.

DOV konstatují, že "je vhodné si uvědomit, že samotné zastávání př́znivých environmentálních postojü ještě nevede $k$ odpovědnému environmentálnímu chování a je pouze jednou z rozvíjených oblastí." (s. 64). Tato formulace je zcela oprávněná, přestože je z pragmatických důvodů zjednodušená. Přesnější by bylo říct, že v odborné literatuře není $v$ otázce vlivu postojů a hodnot na odhodlání k proenvironmentálnímu chování shoda. Podle REB modelu je vliv tzv. obecných proenvironmentálních postojů, tj. stanovisek zaujímaných k obecným otázkám souvisejícím se životním prostředí a jeho ochranou spíše malý (Hungerford \& Volk, 1990). Zajímavý efekt popisují Jurin a Fortner (2002): podle nich vedou obecné proenvironmentální postoje k určitému symbolickému chování. Člověk, který deklaruje souhlas s nutností chránit přírodu, například třídí odpad (což je pro něj snadné, ale má poměrně malý dopad na životní prostředí), ale neomezuje se $v$ jízdě automobilem či létání letadlem (což je pro něj náročnější, ale má mnohem výraznější environmentální dopad). Důvodem je přesvědčení, že volbou malé (symbolické) aktivity toho pro životní prostředí dělá dost a žije $v$ souladu se svým přesvědčením. Ve Sternově modelu VBN ${ }^{3}$ (Stern a kol., 1999) ale naopak biocentrické hodnoty a obecné

\footnotetext{
${ }^{2}$ Tj. motivace, která není vedena instrumentálními pohnutkami.

3 VBN - value-belief-norm theory předpokládá, že základním východiskem proenvironmentálního chování jsou neantropocentrické hodnoty.
} 
proenvironmentální postoje hrají roli základního východiska pro zájem angažovat se v otázkách životního prostředí.

Pravděpodobně větší shoda je na vliv specifických postojů, tj. stanovisek zaujímaných ke konkrétním environmentálním otázkám (např. je správné kupovat si BIO?). Zde se předpokládá silnější vliv na odhodlání k chování, přestože nelze mluvit o jednoduché lineární kauzalitě K-A-B ${ }^{4}$ modelu (Hungerford \& Volk, 1990). Klíčovou větou DOV je doporučení: „Je vhodné zařazovat např́klad diskusní aktivity, ve kterých žáci identifikují vlastní postoje a hodnoty a porovnávají je s hodnotami a postoji ostatních." (s. 64). DOV opět předpokládá, že učitel nemanipuluje žáky k zaujímání postojů, které chce slyšet, a že umožní ve třídě transparentní diskusi podloženou vyváženými argumenty všech zainteresovaných stran.

\section{Závěr}

Ještě před schválením DOV začala o materiálu probíhat diskuse v prostředí středisek ekologické výchovy. Materiál byl také ověřován na několika základních školách a gymnáziích. DOV se staly vstupním východiskem pro probíhající diskusi o vymezení cílů environmentální výchovy v rámci pracovní skupiny na Ministerstvo životního prostředí. vúp navázal projektem metodické podpory implementace na školách.

Jen čas ale prokáže, zda se DOV stanou skutečně tak zásadním bodem obratu domácího pojetí environmentální výchovy, jak autoři doufají. DOV mají nepovinný charakter a jejich implementace tak závisí na zájmu každé školy. Odlišnost jejich pojetí od domácí tradice může vést $\mathrm{k}$ problémům $\mathrm{s}$ jejich interpretací. PIná realizace DOV vyžaduje erudované školní koordinátory environmentální výchovy, kteří se v rámci svého studia naučili rozumět jejich logice. DOV nejsou prosty problematických bodů, ve kterých pracovní skupina musela přijímat nesnadná rozhodnutí, která nemusela být vždy správně zvolena. V době probíhajících diskusí o reformě školství není nakonec jisté ani zachování RVP, ze kterých DOV vychází.

Jak u nás bude vypadat environmentální výchova za pět či deset let? Bude v ní více žákovských projektů, iniciativy dětí, analýzy a řešení konfliktů, či samostatných výzkumů životního prostředí? Nebo zůstane naukou o ekologických pojmech a environmentálních problémech? Podaří se napojit domácí tradici na mezinárodní diskurs, nebo zưstaneme uzavřeni v environmentální výchově „po česku"?

\section{Literatura}

- Ajzen, I. (1991). The Theory of Planned Behavior. Organizational Behavior and Human Decision Process. Organizational Behavior and Human Decision Process, 50, 179-211.

- $\quad$ Ardoin, N. M. . Sense of Place and Responsible Behavior: What the Research Says. [online]. : Yale School of Forestry and Environmental Studies.

- Back, L., \& CABLE, Ted., (2002). Interpretation for the 21st century. Champaign: Sagamore publishing.

- Bardwell, L. V., Monroe, M. C., \& Tudor, M. T. (1994). Environmental Problem Solving. Theory, Practice and Possibilities in Environmental Education. Troy: NAAEE.

\footnotetext{
${ }^{4}$ K-A-B - knowledge-attitude-behaviour model předpokládá, že získávání znalostí vede ke změně postojů a změna postojů pak ke změně chování.
} 
- $\quad$ The Belgrade Charter. A Global Framework for Environmental Education (1975). .

- Environmental Education Research (2002). BOWERS, C.A.. Environmental Education Research, 8(1), 21-34.

- Capra, F. (2007). Sustainable Living. Ecological Literacy, and the Breath of Life. Canadian Journal of Environmental Education, 12, 9-18.

- Činčera, J. (2008). Výchova k udržitelnému rozvoji. Mýtus nebo nová vlna? [online]. Envigogika, 3(1), Retrieved from http://www.czp.cuni.cz/envigogika

- Činčera, J. (2008). Analýza průřezového tématu Environmentální výchova $v$ Rámcovém vzdělávacím programu pro základní vzdělávání [online].Envigogika, 3(2), Retrieved from http://www.czp.cuni.cz/envigogika

- Činčera, J., Jiří, K., \& Gollová, D. (2009). Efektivita, evaluace a podpora programů environmentální výchovy [online].. Envigogika, 4(2), Retrieved from http://www.czp.cuni.cz/envigogika

- Činčera, J. (2010). Metodika evaluace programů environmentální výchovy [online]. Envigogika, 5(3), Retrieved from http://www.czp.cuni.cz/envigogika

- Činčera, J., \& Mašková, V. (2011). GLOBE in the Czech Republic: a program evaluation. Environmental Education Research, 17(4), 499-517.

- De Young, R. (2000). Expanding and Evaluating Motives for Environmentally Responsible Behavior - Statistical Data Included. Journal of Social Issues,56(3),

- Darner, R. (2009). Self-Determination Theory as a Guide to Fostering Environmental Education. Journal of Environmental Education, 40(2), 39-49.

- Disinger, J. F. (2005) Environmental Education's Definitional Problem. In H. H. Hungerford, W. J. Bluhm, T. L. Volk, \& J. M. Ramsey (Eds.), Essential Readings in Environmental Education (pp. 17-31). Champaign: Stipes.

- Disinger, J. F. Environment in the K-12 Curriculum: An Overview. In R. Wilke (Ed.), Environmental Education. Teacher Ressource Handbook. A Practical Guide for K-12 Environmental Education (pp. 23-44). Thousand Oaks: Corwin.

- Gruenewald, D. A. (2008). The best of both worlds: a critical pedagogy of place. Environmental Education Research, 14(3), 308-324.

- Heimlich, Joe E., Ardoin, Nicole M., (2008). Understanding behavior to understand behavior change: a literature review. Environmental education research,14(3), 215-237.

- Hicks, D., \& Bord, A. (2001). Learning about Global Issues: Why most educators only make things worse. Environmental Education Research, 7(4), 413-425.

- Hungerford, H. R., \& Volk, T. L. (2005) Curriculum Development in Environmental Education for the Primary School: Challenges and Responsibilities. In H. H. Hungerford, W. J. Bluhm, T. L. Volk, \& J. M. Ramsey (Eds.), Essential Readings in Environmental Education (pp. 115-126). Champaign: Stipes.

- Hungerford, H. R., \& Volk, T. L. (1990). Changing Learner Behavior Through Environmental Education. The Journal of Environmental Education, 21(3), 8-21.

- Hungerford, H., Peyton, B. R., \& Wilke, R. J. (1980). Goals for Curriculum Development in Environmental Education.. The Journal of Environmental Education,11(3), 42-47.

- Hungerford, H. R. (2005) The General Teaching Model (GTM). In H. H. Hungerford, W. J. Bluhm, T. L. Volk, \& J. M. Ramsey (Eds.), Essential Readings in Environmental Education. Champaign: Stipes. 
- Hungerford, H. R. (2005) The Myth of Environmental Education - Revisited. In H. H. Hungerford, W. J. Bluhm, T. L. Volk, \& J. M. Ramsey (Eds.), Essential Readings in Environmental Education (pp. 49-56). Champaign: Stipes.

- Hwang, Y., Kim, S., \& Jeng, J. (2000). Examining the Causal Relationships Among Selected Antecedents of Responsible Environmental Behavior. The Journal of Environmental Education, 31(4), 19-25. Retrieved from http://www.tandfonline.com/doi/abs/10.1080/00958960009598647 http://dx.doi.org/10.1080/00958960009598647

- Chawla, L. (1999). Life Paths Into Effective Environmental Education. The Journal of Environmental Education. The Journal of Environmental Education, 31(1), 15-26.

- Chawla, L. (1998). Significant Life Experiences Revisited: A Review of Research on Sources of Environmental Sensitivity. The Journal of Environmental Education, 29(3), 11-21.

- Jensen, B. B., \& Schnack, K. (2006). The action competence approach in environmental education. Environmental Education Research, 12(3(2)), 163-178.

- Jurin, Richard R., Fortner, Rosane W., (2002). Symbolic Beliefs as Barriers to Responsible Environmental Behavior. Environmental Education Research, 8(4), 373-394.

- Kahn, R. (2007). Weaving a Broad-based Pedagogy of Liberation for Animals, Nature and the Opressed People of the Earth. : University of North Dakota. Retrieved from http://richardkahn.org/writings/ecopedagogy/towardsecopedagogy.pdf

- $\quad$ Kellert, S. R. (1998). A national study of outdoor wilderness experience. : Yale University.

- Knapp, D. (2005) Environmental Education and Environmental Interpretation: The Relationships.. In H. H. Hungerford, W. J. Bluhm, T. L. Volk, \& J. M. Ramsey (Eds.), Essential Readings in Environmental Education (pp. 349-356). Champaign: Stipes.

- Kollmuss, A., \& Agyeman, J. (2002). Mind the Gap: why do people act environmentally and what are the barriers to pro-environmental behavior?.Environmental Education Research, 8(3), 239-260.

- Krajhanzl, J. (2009). Člověk + príroda = udržitelnost? Texty o proměně vztahů lidí k prírodě, environmentální výchově a udržitelnosti. Praha: Zelený kruh.

- Krajhanzl, J. (2010). Charakteristika osobního vztahu k prírodě. Úvod do teorie a pojmosloví. [Disertační práce]. Praha: UK.

- Lundegård, I., \& Wickman, P. (2007). Conflicts of interest: an indispensable element of education for sustainable development. Environmental Education Research, 13(1), 1-15.

- Marcinkowski, T. (1997) Assessment in Environmental Education. In R. J. Wilke (Ed.), Environmental Education. Teacher Ressource Handbook. A Practical Guide for K-12 Environmental Education (pp. 143-198). Thousand Oaks: Corwin.

- Marcinkowski, T. (2004). Using a Logic Model to Review and Analyze an Environmental Education Program. Washington: North American Association for Environmental Education.

- Marcinkowski, T. (2005) Predictors of Responsible Environemental Behavior. A Review of Three Disertation Studies. In H. H. Hungerford, W. J. Bluhm, T. L. Volk, \& J. M. Ramsey (Eds.), Essential Readings in Environmental Education (pp. 265-294). Champaign: Stipes.

- Naaee, (2004). Excellence in Environmental Education - Guidelines for Learning(Pre K-12. : North American Association for Environmental Education. Retrieved from http://www. naaee.org/npeee/learner guidelines.php

- Östman, L., \& Öhman, J. (2007). Selective traditions within Environmental Education. Durban: WEEC. 
- Palečková, Jana a kol., (2007). Hlavní zjištění výzkumu PISA 2006. Poradí si žáci s prírodními vědami?. Praha: Ústav pro informace ve vzdělávání.

- Palečková, J., Tomášek, V., \& Basl, J. (2010). Hlavní zjištění výzkumu PISA 2010. Umíme ještě číst?. Praha: Ústav pro informace ve vzdělávání.

- PALMER, J. et al., (1998). An Overview of Significant Influences and Formative Experiences on the Development of Adults' Environmental Awareness in Nine Countries. Environmental Education Research, 4(4), 445-464.

- Pastorová, Markéta a kol, (2011). Doporučené očekávané výstupy. Metodická podpora pro výuku prưrezových témat na základních školách. Praha: Výzkumný ústav pedagogický. Retrieved from http://www.vuppraha.cz/nova-publikace-divize-vup-\%E2\%80\%93doporucene-ocekavane-vystupy-pro-zakladni-skoly

- Peterson, N. (2005) Factors Influencing the Development of Environmental Sensitivity. In H. H. Hungerford, W. J. Bluhm, T. L. Volk, \& J. M. Ramsey (Eds.), Essential Readings in Environmental Education (pp. 295-300). Champaign: Stipes.

- Prưcha, J., Walterová, E., \& Mareš, J. (2009). Pedagogický slovník. Praha: Portál.

- Ramsey, J. M., Hungerford, H. H., \& Volk, T. L. (2005) Environmental Education in the K-12 Curriculum: Finding a Niche. In H. H. Hungerford, W. J. Bluhm, T. L. Volk, \& J. M. Ramsey (Eds.), Essential Readings in Environmental Education (pp. 127-140). Champaign: Stipes.

- Räthzel, N., \& Uzzell, D. (2009). Transformative environmental education: a collective rehearsal for reality. Environmental Education Research, 15(3), 263-277.

- Rickinson, M. (2001). Learners and Learning in Environmental Education: a critical review of the evidence. Environmental Education Research, 7(3), 207-320.

- Sauvé, I. (2005). Currents in Environmental Education: Mapping a Complex and Evolving Pedagogical Field. Canadian Journal of Environmental Education,10, 11-37.

- Sellers, J. . Goals. In MEERA Evaluation Glossary. [online]. . Retrieved from http://meera.snre.umich.edu

- Schnack, K. (2009). Action Competence, Conflicting interests and Environmental Education. Copenhagen: Aarhus University. Retrieved from http://www.MUVIN.net

- Sivek, D. J. (2002). Environmental Sensitivity among Wisconsin High School Students. Environmental Education Research, 8(2), 155-170.

- Sobel, D. (2005). Place-Based Education: Connecting Classrooms \& Communities. Barrington: The Orion Society.

- Stapp, W. B. (2005) The Concept of Environmental Education. In H. H. Hungerford, W. J. Bluhm, T. L. Volk, \& J. M. Ramsey (Eds.), Essential Readings in Environmental Education (pp. 33-36). Champaign: Stipes.

- Sterling, S. (2001). Sustainable education. Re-visioning Learning and Change. Bristol: Green Books; The Schumacher Society.

- Stern, P. C., Dietz, T., Troy, A., \& Guagnano, Gregory A., KALOF, Linda., (1999). A ValueBelief-Norm Theory of Support for Social Movements: The Case of Environmentalism. Human Ecology Review, 6(6), 81-97.

- Sward, L. L., \& MARCINKOWSKI, Tom., (2005) Environmental Sensitivity: A Review of the Research, 1980-1998. In H. H. Hungerford, W. J. Bluhm, T. L. Volk, \& J. M. Ramsey (Eds.), Essential Readings in Environmental Education (pp. 301-312). Champaign: Stipes.

- Essential Readings in Environmental Education (2005) The Tbilisi Declaration. Intergovernmental Conference on Environmental Education. In H. H. Hungerford, W. J. Bluhm, T. L. Volk, \& J. M. Ramsey (Eds.), (pp. 13-16). Champaign: Stipes. 
- Vadala, C. E., Bixler, R. D., \& JAMES, J. Joy, (2007). Childhood Play and Environmental Interest: Panacea of Snake Oil?. The Journal of Environmental Education, 39(1), 3-18.

- Volk, T. L. (2005) Integration and Curriculum Design. In H. H. Hungerford, W. J. Bluhm, T. L. Volk, \& J. M. Ramsey (Eds.), Essential Readings in Environmental Education (pp. 141-160). Champaign: Stipes.

- Wals, A. (2009). Review of Contexts and Structures for Education for Sustainable Development. Paris: Unesco.

- Braniš, M. (1997). Základy ekologie a ochrany životního prostředí: Učebnice pro střední školy. Praha: Informatorium. 
Časopis Envigogika vydává Centrum pro otázky životního prostředí UK. Vývoj časopisu je podpořen projektem OP VK Mezioborová sít udržitelného rozvoje.

Více najdete na internetových stránkách projektu mosur.czp.cuni.cz
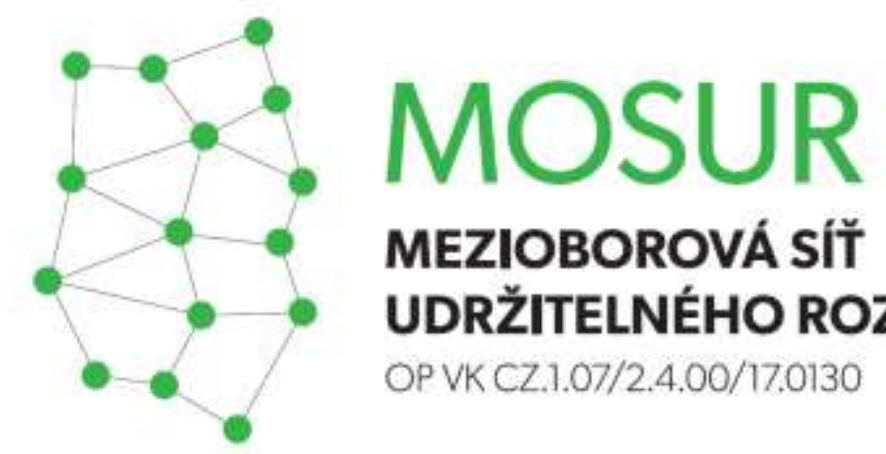

\section{MEZIOBOROVÁ SÍT} UDRŽITELNÉHO ROZVOJE

OP VK CZ.1.07/2.4.00/17.0130
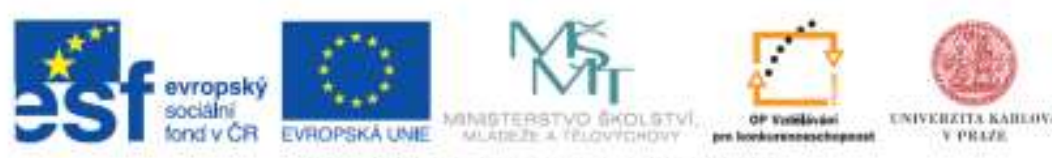

INVESTICE DO ROZVOJE VZDELAVANI 